\title{
STRATEGI KOMUNIKASI INTERPERSONAL PENYULUH AGAMA BUDDHA DALAM MENINGKATKAN KEAKTIFAN UMAT UNTUK MENGIKUTI KEGIATAN DI VIHARA KABUPATEN KULON PROGO
}

\author{
Sumar $^{1}$, Sutrisno ${ }^{2}$, Sudarto $^{3}$
}

\begin{abstract}
ABSTRAK
Penyuluh merupakan orang yang memberi petunjuk berupa bimbingan, arahan kepada orang lain sehingga orang tersebut mampu memahami informasi yang ada di Vihara. Penyuluh agama diharapkan mampu memberi pengayoman dan bertindak sebagai teman baik, mampu memenuhi kebutuhan umat dalam pelayanan keagamaan. Agama menjadi pedoman masyarakat untuk menjadi manusia yang lebih baik. Praktek agama menjadi tolak ukur baik tidaknya seseorang dalam kehidupan bermasyarakat. Hal tersebut yang menyebabkan agama memiliki peran dominan dalam membentuk dan menciptakan kondisi yang baik dalam masyarakat.
\end{abstract}

Kata Kunci: Komunikasi Interpersonal, Penyuluh Agama Buddha

\section{ABSTRACT}

The instructor is a person who gives instructions in the form of guidance, direction to others so that the person is able to understand the information in the Vihara. It is hoped that the religious instructor will be able to provide protection and act as good friends, able to meet the needs of the people in religious services. Religion becomes the guideline for society to become a better human being. Religious practice is a measure of whether a person is good or not in social life. This causes religion to have a dominant role in shaping and creating good conditions in society.

Keywords: Interpersonal Communication, Buddhist Religious Counselor

\footnotetext{
${ }^{1}$ Kepanditaan Buddha STABN Raden Wijaya, email: leksumar3@gmail.com

${ }^{2}$ STABN Raden Wijaya, email: dutaarya25@gmail.com

${ }^{3}$ STABN Raden Wijaya, email: dartosudarto13@gmail.com
} 


\section{Pendahuluan}

Peran penyuluh agama dalam kehidupan di masyarakat adalah membentuk perilaku yang baik dan mengembangkan kebaikan dalam menciptakan kondisi-kondisi yang ideal. Sebagai salah satu contoh keberadaan penyuluh agama Buddha di Kabupaten Kulon Progo adalah untuk menciptakan sebuah kondisi yang baik didukung dengan adanya partisipasi dari umat secara luas sehingga peran seorang penyuluh agama dapat memberikan kondisi yang ideal. Selain itu keberadaan agama Buddha menjadi salah satu modal yang besar dalam pembentukan prilaku masyarakat umat Buddha.

Seperti yang di jelaskan Agus Mulyono (2014:163) penyuluh agama mempunyai fungsi informastif, edukatif, konsulatif, advokatif dan administrative. Keberadaan penyuluh mampu memberi informasi keagamaan baik sebuah kegiatan atau pengetahuan tentang ajaran Buddha untuk mengajak masyarakat menjalankan ajaran agama dalam kehidupan sehari-hari. Ajaran agama dapat diperoleh melalui aktif dalam mengikuti kegiatan keagamaan. Kegiatan keagamaan dapat dimunculkan oleh para pemuka agama dalam berbagai bentuk kegiatan. Bentuk kegiatan-kegiatan tersebut dapat berupa pujabakti di Vihara, diskusi umat Buddha, pendidikan, yang dilakukan oleh para pemuka dan petugas resmi yang ditunjuk oleh lembaga agama dan yayasan keagamaan.

Kegiatan diatas merupakan tugas dari seorang penyuluh, yang mempunyai tanggung jawab secara utuh untuk memberikan bimbingan serta arahan terhadap umat Buddha khususnya di Kabupaten Kulon Progo. Hal ini selaras dengan pelayanan keagamaan yang diungkapkan oleh Supartini (2007:42) bahwa pelayan keagamaan yang diberikan kepada umat Buddha mencakup tiga hal yaitu, pembinaan bimbingan dan penerangan agama, pembinaan saranan keagamaan Buddha, pembinaan pendidikan agama dan keagamaan Buddha. Pengertian di atas menjelaskan bahwa tugas penyuluh agama sangat penting untuk keberlangsungan umat yang ada di Kabupaten Kulon Progo.

Keberlangsungan tugas penyuluh agama Buddha diharapkan mampu memberikan pengayoman dan bertindak sebagai teman yang baik, mampu 
memenuhi kebutuhan umat dalam pelayanan keagamaan. Penyuluh dalam agama Buddha memiliki salah satu fungsi sebagai Dharmaduta. Contoh kasus yang ada di Vihara Giriloka seperti yang di sampaikan oleh Susanto (pengurus Vihara) pada tanggal 13 febuari 2020 menyatakan di Vihara Giriloka terdapat kegiatan puja bakti malam Selasa Kliwonan, malam kamisan, puja bakti siang jam 14.00 dan Atthasila di tanggal Uposatta. Pada kegiatan tersebut jumlah umat yang datang sekitar 10 orang. Pada tanggal 11 januari 2020 bapak Bari juga mengatakan kegiatan Atthasila di tanggal Uposatta hanya sekitar 20 orang, sedangkan umat Buddha Vihara Giriloka sekitar 300 umat. Menurut bapak Supriyanto selaku pengurus vihara menyatakan bahwa di Vihara Girisurya umat yang mengikuti kegiatan pujabakti keliling yang datang rata-rata setengah dari jumlah keseluruhan umat Buddha. Salah satu umat di Vihara Giriloka Lamano mengatakan, mau datang ke Vihara tidak enak karena dia sungkan, canggung dan merasa tidak diajak. Wawancara ini dilakukan pada bulan November 2019
Seorang penyuluh harus mampu meningkatkan kualitas dirinya, baik dalam bidang keagamaan, pendidikan maupun layanan sosial kemasyarakatan yaitu dengan memberikan ceramah Dhamma atau pengetahuan umum kepada umat Buddha, mampu menyampaikan materi dengan jelas, tepat serta dapat dipahami oleh umat serta mampu mengaplikasikan komunikasi interpersonal yang baik dengan umat.

Komunikasi mempunyai peran penting dalam memberikan kontribusi yang besar untuk meningkatkan hubungan antar umat manusia. Dalam kamus besar bahasa Indonesia (KBBI) "komunikasi adalah pengiriman dan penerimaan pesan dan berita antara dua orang atau lebih sehingga pesan yang dimaksud dapat dipahami" (Wursanto, 2005:153). Tanpa komunikasi kita tidak bisa berbagi pengetahuan atau pengalaman dengan orang lain, proses komunikasi dalam hal ini bisa melalui menyampaikan pesan dari pihak pengirim ke penerima pesan, ucapan, tulisan, gerak tubuh dan penyiaran.

Menurut Kathleen S. Verderber (dalam Budyatna dan Ganiem, 2011:14) komunikasi interpersonal adalah proses 
melalui mana orang menciptakan dan mengelola hubungan mereka, melaksanakan tanggung jawab secara timbal balik dalam menciptakan makna. Dengan demikian komunikasi interpersonal yang dilakukan oleh penyuluh agama sangat berpengaruh terhadap umpan balik yang akan diterima oleh umat Buddha.

Kondisi di lapangan Komunikasi interpersonal seorang penyuluh agama belum sesuai dengan komunikasi interpersonal yang sesuai pada umumnya, sehingga hal tersebut mengakibatkan kurang aktifnya umat mengikuti kegiatan di Vihara. Beberapa hal yang ada dalam lingkungan masyarakat yang diperoleh peneliti pada saat melakukan observasi pada masyarakat umat Buddha di Kabupaten Kulon Progo dengan salah satu Vihara. Kurangya komunikasi secara menyeluruh serta kurangnya pembinaan umat baik oleh lembaga terkait maupun petugas yang bertanggungjawab pada bidang pelayanan umat.

Kodisi demikian merupakan kondisi yang riskan untuk keberlangsungan umat Buddha di wilayah Kulon Progo, sehingga kondisi tersebut diharapkan agar menjadi sebuah kondisi yang ideal. Kondisi ideal menjadi umat Buddha adalah dengan melaksanakan dan mengamalkan ajaran agama dalam kehidupan sehari-hari. Selanjutnya peneliti dengan melihat kondisi demikian memiliki gagasan untuk melaksanakan penelitian tentang strategi komunikasi interpersonal penyuluh agama dalam meningkatkan keaktifan umat untuk mengikuti kegiatan Kabupaten Kulon Progo.

\section{ME|TODE}

Penelitian ini dilaukan selama enam nulai febuari - juli dengan mengunakan metode kualitaitf. Dalam penelitian ini peneliti mengunakan pendekatan study kasus. peneliti berusaha menggali strategi komunikasi interpersonal penyuluh agama untuk mengingkatkan keaktifan umat mengikuti kegiatan di vihara. pengumpulan data dilakukan dengan teknik observasi, wawancara dan dokumentasi. Teknik pengambilan sample mengunakan teknik sampling purposive. Teknik keabsahan data mengunakan triangulasi data dan sumber. Penelitian ini mengunakan teknik 
analisisi data digunakan model analisis interaktif.

\section{Hasil dan Pembahasan}

\section{Strategi komunikasi interpersonal} penyuluh agama

Strategi komunikasi interpersonal adalah perencanaan dam menejemen komunikasi penyuluh agama dalam penyampaian informasi, pikiran dan sikap tertentu antara dua orang atau lebih yang terjadi saling bergantian pesan sebagai komunikan maupun komunikator untuk mencapai tujuan yang sama dengan menunakan kata-kata yang baik dan bijaksana sehingga, timbul adanya saling pengertian mengenai masalah yang dibicarakan. Hal ini diharapkan tercapainya tujuan yang sama untuk membangun kedekatan antara individu dan mendapatak hal yang lebih baik dalam mencapai suatu tujuan. Dalam menyampaikan sesuatu dapat mengunakan berbagai cara sesuai dengan karakter dan jumlah umat yang ada di daerah tersebut. Ada tiga strategi komunikasi penyuluh agama yaitu ;

\section{a. Tatap muka}

Peneliti melakukan melakukan wawancara dengan penyuluh agama buddha yang ada di daerah Kulon Progo. Untuk vihara Girisurya peneliti melakukan wawancara dengan Bapak Budi Supradi selaku Ketua Vihara dan penyuluh agama Buddha mengatakan bahwa;

"Vihara Girisurya yang mempunyai jumlah umat 150 . Untuk melakukan pendekatan dengan umat Strategi komunikasi yang di gunakan dalam menyampaikan informasi kegiatan Vihara tidak harus dalam kegiatan Formal akan tetapi di selipkan dalam setiap ketemu dengan umat entah itu di acar genduri, ketemu dijalan, pada saat ngopi bersama dan sebagainya"

Dari wawancara di atas Vihara Girisurya memiliki jumlah umat 150 orang. Umat Buddha di vihara ini banyak yang bekerja di rumah atau di lingkup Kulon Progo sehingga, sering bertemu dengan penyuluh agama. Hal ini mempermudah penyuluh agama menyampekan informasi-informasi yang ada berkaitan dengan kegiatan vihara. Seperti yang di katakan Bapak supriadi setiap bertemu dengan umat baik itu acara kerjabakti, bertemu di warung, bertemu di jalan, di acara genduri dan acara puja bakti di rumah umat selalu menyampekan informasi- 
informasi yang berkaitan dengan kegiatan vihara.

Penyuluh agama Buddha

Vihara Giridharma mempunyai cara tersendiri unutk melakukan komunikasi dengan umat. Ibu purwanti selaku penyuluh agama Buddha di Vihara GiriDharma mengatakan;

"Dalam menyampaikan informasi terkait dengan kegiatan vihara penyuluh datang kerumah umat"

Cara menyampekan informasi penyuluh agama Buddha di Vihara Giridharma salah satunya datang kerumah umat. Cara ini dilakukan bagi umat yang tidak sbuk bekerja diluar. Penyuluh agama Buddha Vihara Giriloka mengunakan cara yang sama seperti yang dilakukan penyuluh agama Buddha Giridharma Ibu purwanti. Penyuluh agama Buddha Giriloka bapak Ramlan mengatakan;

"Sebelum Virus Korona

merebah di Indonesia penyuluh agama sering datang kerumah umat untuk menyampakan informasi-informasi kegiatan Vihara"

Strategi Dor To Dor juga dilakuakan Di Vihara Dharma Mulya. Di Vihara ini untuk menyampekan informasi yang ada di Vihara langsung datang kerumah umat, seperti yang dikatakan Ibu Suprihatin dibawah ini ; "Jumlah umat Buddha yang ada di Vihara Dharma Mulya 14 orang rata mereka berusia tua sehingga, untuk menyampekan komunikasi kegiatan Vihara dengan cara datang kerumahrumah umat. Ini lebih efektif karena jarak tiap rumah tidak jauh"

Setiap vihara mempunyai karakteristik tersendiri mulai dari jumlah umat, usia umat dan letak vihara. Penyuluh agama mempunyai cara tersendiri dalam menuyampaikan komunikasi ke umat. Seperti yang ada di vihara Dharma Mulya yang jumlah umatnya 14 orang akan lebih mudah dalam menyampekan infromasi walapun umat yang ada di vihara ini rata-rata berusia tua. Umat Buddha yang ada di Vihara ini merupakan satu keluarga besar dari simbah-simbah mereka masih satu trah.

Strategi dalam komunikasi adalah cara mengatur pelaksanaan oprasi komunikasi agar berhasil. Strategi komunikasi pada hakikatnya adalah perencanaan (planning) dan manajemen (magement) untuk mencapai satu tujuan. Untuk mencapai tujuan tersebut, strategi tidak berfungsi sebagai 
peta jalan yang hanya menunjukkan arah, tetapi juga harus menunjukkan taktik oprasionalnya (Yusuf Zainal Abidin, 2015:155). Oleh karenanya dari paparan secara teori diatas, agar komunikator Pada saat berkomunikasi harus bisa membuat strategi komunikasi terlebih dahulu agar pesan yang kita sampaikan bisa mencapai target komunikasi yang diinginkan.

Komunikasi adalah proses penyampaian suatu pesan dalam bentuk simbol atau kode dari dari satu pihak kepada yang lain dengan efek untuk mengubah sikap, atau tindakan.

Dari hasil wawancara di atas peneliti dapat menarik kesimpulan bahwa setiap strategi komunikasi interpersonal yang dilakukan penyuluh agama datang kerumah umat. Penyuluh Vihara Dharma mulya yang paling aktif bertatap muka dengan umat.

\section{b. Melalui Media Sosial}

Media sosial menjadi cara kedua yang di lakukan penyuluh agama Buddha di Kulon Progo untuk meningkatkan keaktifan umat mengikuti kegiatan di Vihara. Seperti penyuluh agama Buddha Vihara Giri Dharma ibu Purwanti mengatakan;
"Whatsapp menjadi penghubung umat. dengan adanya whatsapp mempermudah penyuluh menyampaikan informasi terkait kegiatan Vihara dan melakukan pendekanan dengan umat"

Di Vihara Giriloka penyuluh agama Buddha mengunakan Media sosial untuk melakukan pendekan dengan umat Buddha. Cara ini dilakukan karena banyak umat yang susah untuk bertemu. Di Vihara Giriloka banyak umat yang sibuk bekerja di kota dan ada beberapa umat yang masih kuliah. Seperti yang dikatakan bapak Ramlan ;

"Untuk melakukan komunikasi dengan umat yang sibuk bekerja dan sibuk kuliah mengunakan media sosial Aplikasi Whatsapp"

Dari kedua pendapat di atas penyuluh agama mengunakan media sosial sebagai media komunikasi ke umat dalam meningkatkan keaktifan umat mengikuti kegiatan di Vihara.

\section{c. Dari Mulut Ke Mulut}

Penyampaian informasi

melalui dari mulut kemulut digunakan penyuluh agama kepada umat yang tidak ada dirumah dan tidak mempunyai 
media sosial. Seperti yang dikatakan bapak Budi;

"Dalam menginformasikan tentang kegiatan yang ada di Vihara dapat dilakukan dengan menyebar infomasi dari mulut ke mulut atau menitipkan pesan dari mulut ke mulut"

Cara ini di gunakan penyuluh agama kepada umat yang susah bertemu. Banyak umat yang mempunyai kesibukan tersendiri baik itu bekerja di luar daerah, bekerja di kota maupun sibuk sekolah. Penyuluh agama Giriloka dan Giridharma memgatakan hal yang sama yaitu;

"alternative menyampekan informasi terkait kegiatan vihara kepada umat yang jarang ketemu menitipkan pesan omongan ke umat lain"

Dari beberapa pendapat penyuluh di atas dapat disimpulkan menginformasikan kegiatan vihara dapat dilakukan dengan cara menitipakan pesan kepada umat yang dirumah ke umat yang jarang bertemu.

\section{Kendala Komunikasi Penyuluh}

\section{a. Umat Berusia Lanjut}

Kendala yang dialami penyuluh agama Buddha berbeda-beda dari jumlah umat, umat yang berusia lanjut dan umat yang bekerja di luar Kulon progo. Peneliti melakukan penelitian kepada seluruh penyuluh agama Buddha di setiap Vihara yang ada di Kulon Progo. Peneliti melakukan penelitian kepada penyuluh agama Buddha Vihara Dharma Mulya ibu Suprihatin. Beliau mengatakan terkait dengan dengan kendalam yang ada dalam menyampekan strategi komunikasi tentang kegiatan yang ada Di Vihara, ibu Suprihatin katakan ;

"Di Vihara Dharma Mulya umatnya sudah tua-tua yang muda hanya 2 orang sedangkan yang kecil 2 orang dan yang aktif hanya tua-tua. Untuk memyampekan informasi terkait dengan kegiatan di Vihara harus keliling kerumah umat. Sedangkan waktu kegiatan tidak bisa lama. Jumlah umat yang rata-rata berusia tua harus menyesuaikan kegiatan dengan usia umat penyuluh juga harus lebih aktif pendekatan ke umat karena jumlah umat sedikit".

Selain melakukan wawancara kepada penyuluh agama Peneliti juga melakukan wawancara terhadap salah satu umat Vihara Dharma Mulya yaitu Ibu Sarini dan anaknya Mei Sucitta Dewi mengatakan ; 
"Kegiatan yang di Vihara Dharma mulya puja bakti minggu siang jam 3 sore, malam kamis latihan meditasi dan kegiatan bercocok tamanan organik. Kegiatan ini selain bisa menjadi pedapatan vihara juga bisa merasakan hasil panenan karena sebagain dibagi ke umat. Yang tidak aktif ke Vihara 2 orang karena mereka sudah sepuh. Sedangkan untuk kegiatan yang lain yang datang 5 sampai 10 orang. Kendala yang paling terasa di vihara ialah jumlah umat sedikit dan jumlah umat tuatua. Harus mempunyai perhatian yang ekstra ke umat".

Jumlah umat yang tergolong sedikit dan rata-rata umat berusia tua menjadi kendala dalam kegiatan yang lain. Seperti yang di katakan ibu suprihatin minat untuk mengikuti kegiatan yang lain setengah dari jumlah umat. Usia tua yang rentang hanya bisa mengikuti kegiatan bercocok tanam itupun yang ibu suprihatin yang banyak mengeluarkan tenaga. Di lingkungan vihara yang rata-rata sebagai petani dan ternak kambing etawa, umat harus membagi waktu dan tenaga untuk mengikuti kegiatan tersebut.

\section{b. Umat Jarang Dirumah}

Banyaknya umat yang jarang dirumah menjadi masalah tersendiri bagi penyuluh agama. Berikut wawancara dengan penyuluh agama Buddha Vihara Giridharma ibu Purwanti mengatakan ;

"Vihara Giridharma terdapat 120

Umat. Umat Buddha yang di vihara

Giridharma banyak pekerja yang berkeluarga juga sudah fokus sama keluarga masing-masing. Untuk kegiatan di siang hari umat lebih mementingkan bekerja unutk keluarga mereka. Untuk malam harinya umat sudah kecapekan dan umat memlilih beristirahat di rumah". Disini Ibu purwanti lebih mengerakan ibu-ibu unutk datang ke Vihara".

Hal ini senada dengan ucapan Ketua vihara Giridharma Bapak Pairi mengatakan ;

"Di vihara Giridharma umat sudah sibuk bekerja sedangkan yang berkeluarga sudah sibuk dengan keluarga"

Vihara Giridharma yang memiliki jumlah umat 120 orang akan lebih sulit dalam melakukan sosialisasi karena dari jumlah tersebut ada yang bekerja di luar wilayah dan umat yang 
berkeluaraga sibuk bekerja kalau malam sudah kecapekan. Dibutuhkan perhatian lebih dalam mengkoordinasi umat, bagi yang jarang dirumah harus aktif melakukan komunikasi melalui media sosial.

Kendala yang ada vihara Giriloka hampir sama dengan yang di alami Vihara Giridharma. Banyak umat Buddha di Vihara ini berkerja diluar wilayah Kulon progo. Karena bekerja umat Buddha di Vihara ini hanya mengikuti kegiatan Vihara tertentu. Berdasarkan wawancara dengan ketua Vihara Giriloka bapak Harsana mengatakan ;

"Umat Buddha yang mengikuti kegiatan di Vihara Giriloka sebelum Corona $60 \quad \%$ dari jumlah keseluruahan 240 orang kecuali puja bakti keliling yang $80 \%$ \%“.

Pernyataan tersebut di dukung apa yang sampaikan penyuluh agama Buddha Vihara Giriloka bapak Ramlan ; "Sebelum ada virus corona kegiatan di Vihara aktif sekitar 30 orang sampe 40 orang itu perwakilan perkeluarga, setelah adanya korona menjadi vakum. Banyak pemuda yang ada di Vihara Giriloka bekerja, kuliah dan banyak yang pergi keluar kota. Untuk yang aktif ke Vihara di dominasi golongan tua. Pekerja dan mahasiswa hanya mempunyai waktu aktif mengikuti kegiatan di Vihara".

Vihara giriloka yang jumlah umatnya 240 orang menjadi salah satu Vihara yang memiliki jumlah umat terbanyak di kulon progo. Sama seperti yang di alami di Vihara Giridharma umat yang kuarang aktif ke Vihara dikarenakan umat sibuk bekerja di pagi hari dan malamnya beristirahan di ruamah. Sedangkan pemuda yang kuliah kurangnya waktu untuk berpartisipasi dalam kegiatan Vihara. Dari kedua kendala tersebut menjadi kesulitan tersendiri bagi penyuluh agama di Vihara Giriloka.

Kendala yang ada di Vihara Girisurya sama serpti yang ada di Vihara Giridharma dan Vihara Giriloka. Walupun di Vihara ini ratarata tidak bekerja di luar wilayah Kulon Progo banyak umat karena kesibukan bekerja sehingga tidak bisa mengikuti kegiatan Vihara. Untuk kegiatan Vihara di malam hari umat yang kecapekan bekerja di siang hari mereka tidak bisa mengikuti kegiatan di malam hari. Hal ini seperti yang 
dikatakan Penyuluh agama di vihara Girisurya bapak Budi Supriadi mengungkapkan;

"Ada beberapa umat yang sulit untuk di ajak ke Vihara dengan alasan apalagi umat yang punya kesibukan tersendiri dan ada umat yang bekerja ataupun kuliah di luar daerah tapi cuma beberapa orang. Mereka kurang aktif dalam kegiatan Vihara. Akan tetapi secara keseluruhan umat aktif unutk krgiatan di Vihara"

Ini senada dengan salah satu umat di Vihara ini ibu Suwanti mengatakan;

"Di vihara Girisunya ada umat yang kurang aktif ke vihara karena pekerjaan dan perkuliahan tapi tidak banyak".

Selain melakukan wawancara dengan ibu Suwanti peneliti juga melakukan wawancara dengan umat lainya di Vihara Girisurya yaitu bapak Sarino. Bapak sarino juga mengungkapkan seperti ibu Suwati. Bapak Sarino mengungkapkan:

"umat yang disibukan dengan pekerjaan mereka terkolong kurang aktif, sedangkan yang kuliah mengikuti kegitatan vihara hanya pada saat mereka pulang”
Secara keseluruhan tingkat keaktifan di Vihara ini baik hanya sebagian kecil saja yang kurang aktif dalam kegiatan di Vihara. Umat yang jarang mengikuti kegiatan vihara karena dari mereka sibuk bekerja dan malam harinya umat beristirahat di rumah. Umat muda yang kurang aktif ke Vihara hanya beberapa orang, mereka di sibukan dengan perkuliahan.

Dari beberapa pendapat di atas mulai penyuluh agama, umat dan ketua Vihara dapat di sumpulkan bahwa kendala penyuluh agama bagi umat yang kurang aktif mengikuti kegiatan Vihara adalah banyak umat yang mempunyai kesibukan tersendiri seperti kuliah dan bekerja. Bagi pekerja dan mahasiswa hanya bisa mengikuti kegiatan vihara tertentu. Umat Buddha yang kurang aktif ini bisa mengikuti kegitaan Vihara pada saat mereka pulang kampung.

\section{Cara Meningkatkan Keaktifan Umat}

Banyak cara yang dapat dilakukan untuk meningkatkan keaktifan umat mengikuti kegiatan di vihara;

\section{Motivasi}

Di vihara Dharma Mulya penyuluh agama Buddha mempunyai cara tersendiri untuk meningkatkan keaktifan umat untuk mengikuti kegiatan vihara. Penyuluh agama di ini mengunakan pendekatan antar pribadi 
yaitu dengan cara memberi motivasi kepada umat. Jumlah umat yang sedikit mempermudah dalam melakukan pendekatan umat. Selain dengan pendekatan pribadi penyuluh agama di Vihara ini juga mengundang nara sumber sebagai motivator umat. Seperti yang dikatan Ibu suprihatin mengungkapkan ;

"Cara meningkatkan keaktifan di vihara Dharma mulya melakukan pendekatan secara pribadi unutk memberi motivasi umat untuk mengikuti kegiatan di vihara. Selain itu juga mendatangkan narasumber untuk memberi motivasi kepada umat".

Seperti yang dilakukan penyuluh agama yang lainya, penyuluh agama di vihara Dharma mulya mengunakan narasumber sebagai motivasi umat untuk aktif mengikuti keegiatan vihara dan melakukan pendekakan secara individu unutk memotivasi umat untuk aktif mengkuti kegiatan vihara. Sama seperti yang dilakukan bapak Budi Supradi sebagai penyuluh umat Buddha di Vihara Girisurya mengatakan ;

"Untuk mengingkatkan keaktifan umat Buddha di Vihara Girisurya dengan cara memberi motivasimotivasi secara secara tidak langsung setiap bertemu berbagai acara baik formal maupun non formal. Selain itu merangsangan kepada umat untuk ikut memberi ide-ide dalam kegiatan vihara maupun memunculkan kegiatan baru. Vihara Girisurnya juga mengundang narasumber untuk dhammadesana sebagai motivator umat untuk mengikuti kegiatan vihara".

Ini senada dengan Yamin Martimis (2007:84) keaktifan di pengaruhi oleh beberapa faktor yang mempengaruhi keaktifan dalam mengikuti kegiatan memberikan motivasi atau menarik perhatian, sehinga mereka berperan aktif dalam kegiatan organisasi, memunculkan aktifitas, partisipasi kegiatan organisasi, memberi stimulus (masalah, topik, dan konsep yang akan di bahas dalam organisai), memberi umpan balik (feed back) dan meningkatkan kompetensi diri kepada generasi muda.

\section{Arisan}

Arisan menjadi cara mengajak umat untuk mengikuti kegiatan vihara juga di lakukan penyuluh agama Buddha Vihara Giridharma. Akan tetapi arisan bukan menjadi hal yang utama umat datang ke Vihara. Penyuluh mengutamakan diskusi umat serta sembayang, arisan sebagi alat 
mengumpul umat datang ke vihara. penyuluh agama Buddha di vihara Giridharma ibu Purwanti mengatakan ;

"Untuk mengingkan keaktifan umat untuk mengikuti kegiatan di Vihara mengunakan cara memberi motivasi kepada ibu-ibu rumah tangga karena yang muda dan kepala rumah tangga sibuk bekerja mencari nafkah. Cara lain yang dilakukan melakukan arisan dalam kegiatan puja bakti keliling jumat Kliwon dan jumat legi, arisan bukan memenjadi hal yang utama umat datang ke Vihara, arisan hanya sebagai alat mengumpulan umat".

Vihara Giriloka dan vihara Giridharma memiliki cara yang sama untuk meningktakan keaktifan umat unutk mengikuti kegiatan Vihara. Kedua vihara ini mengunakan arisan sebagai alat mengumpulan umat untuk mengikuti kegiatan vihara dan narasumber sebagai motivator umat untuk lebih aktif mengikuti kegiatan vihara. Cara ini dilakukan karena mengumpulkan umat sulit. Banyak umat yang bekerja di luar wilayah dan unutk kepala keluarga sibuk mencari nafkah. Cara ini tergolong berhasil di Vihara Giridharma walaupun tidak signifikan.

\section{Menurut Umat}

Banyak cara yang dapat dilakukan untuk meningkatkan keaktifan umat mengikuti kegiatan di vihara salah satu caranya adalah diskusi dengan umat yang berkompeten unutk membantu memecahkan masalah ini. Salah satu umat di vihara Giriloka bapak Eko Susanto mengatakan ;

"Kegiatan seharusnya sebagai pengerak umat dan membutuhkan pemuda yang aktif untuk mengerakan umat mengikuti kegiatan vihara".

Dari perkataan bapak Eko Susanto kegiatan yang ada di vihara diharapkan menjadi pengerak umat membuat semangat Vihara. Maksud dari pengerak umat adalah kegiatan vihara timbul dari pribadi - pribadi umat sehingga umat cenderung aktif mengikuti kegiatan tersebut. Umat akan menyukai kegiatan yang ada karena kegiatan ini timbul dari umat. Diperlukan kedekatan antarpribadi yang baik untuk memuculkan ide - ide yang dari umat. Dibutuhakan beberapa umat yang tinggal di kampong dan aktif dalam kegiatan vihara untuk merangkul umat yang lain terutama pemuda Buddhis. Ini akan membantu pengurus untuk mengkoordiner umat yang tidak aktif. 
Dari data di atas dapat disimpulakn untuk meningkatkan keaktifan umat dalam mengikuti kegiatan vihara mempunyai cara yang sama yaitu melakukan pedekatan atarpribadi untuk memberi motivasi kepada umat agar dapat aktif mengikuti kegiatan vihara, membutuhkan motivator dalam upaya meningkatkan keaktifan umat mengikuti kegiatan, mencari solusi pemicu umat datang ke Vihara salah satunya arisan dan melakukan diskusi dengan umat unutk memunculkan ide - ide umat dalam memajukan Buddha Dhamma.

\section{Kesimpulan}

Berdasarkan hasil pembahasan data yang sudah dilakukan peneliti. Maka dapat disimpulan bahwa komunikasi interpersonal yang dilakukan penyuluh agama dalam meningkatkan keaktifan umat untuk

\section{DAFTAR PUSTAKA}

Budyatna, Muhammad \& Ganiem, M. Leila. (2011). Teori Komunikasi antar pribadi. Jakarta: Kencana.

Cangara, Hafaid. (2004). Pengantar Ilmu Komunikasi. Jakarta: PT. Raja Grafindo Persada.

Dewa Ketut Sukardi. (1995). Proses Bimbingan Dan Penyuluhan. Jakarta: PT Rineka Cipta.

Hidayat,Dasrun. (2012). Komunikasi Antarpribadi dan Medianya. Yogyakarta: Graha Ilmu. mengikuti kegiatan di Vihara Kabupaten Kulon Progo bermacam-macam caranya. Penyuluh agama aktif kerumah umat melakukan pendekatan secara individu untuk meningkatkan komunikasi interpersonal kepada umat. Selain datang kerumah penyuluh agama dapat melakukan pendekatan dalam berbagai kesempatan guna mengingkatan kedekatan ke umat dengan mengunakan komunikasi interpersonal. Media sosial membantu meningkatkan komunikasi interpersonal penyuluh agama. Melalui media sosial penyuluh agama dapat berintaksi secara langsung unutk umat yang jarang bertemu. Berbincang-bincang dengan umat dengan media sosial cukup membantu mengingkatkan komunikasi interpersonal penyuluh agama guna menyampekan informasi terkait kegiatan di Vihara.

Horby, A S. (1989). OXFORD ADVANCED LEARNER'S DICTIONARY., Fourth Edition. Oxford: Oxford University Press.

Jalaluddin rakhmat. (2009). Psikologi Komunikasi. Edisi Revisi, Bandung: Remaja rosdakarya.

Mudjiono, Yoyon. (2007). Ilmu komunikasi. Surabaya: dakwah Digital Press.

Mulyana, Deddy. (2001). Human Communication Context - Konteks Komunikasi. Bandung: PT. Remaja Rosdakarya. 
(2005). Ilmu

Komunikasi Suatu Pengantar. Bandung: Remaja Rosda Karya.

Mulyono, Agus. (2014). Pemberdayaan Penyuluh Agama Dalam Peningkatan

Pelayanan Keagamaan di Kota Medan. Jakarta: Harmoni.

Onong Uchjana Effendy. (2002). Ilmu Komunikasi Teori Dan Praktek. Bandung: PT Remaja Rosdakarya.

Priastana, Jo. ( 2005). Komunikasi dan Dharmaduta. Jakarta: Yayasan Yasodara Puteri.

Puja Subekti. (2016). Jurnal Faktor-Faktor Dominasi Jumlah Kaum Wanita Dalam Kegiatan Pujabahakti Umat Buddha di Vihara. Vol.2 No.1. Jurnal Pelita Dharma.

Ratna Nyoman Kutha. (2010). Teori, Metode, dan Teknik Penelitian Sastra. Yogyakarta: Pustaka Pelajar

Sardiman. (2001). Interaksi dan Motivasibelajar Mengajar. Jakarta: Raja Grafindo Persada.

Soekamto, Sarjono. (2000). Kamus Sosiologi. Jakarta: Raja wali Press.

Supartini, dkk. ( 2007). Pola Pembinaan Lembaga Keagamaan Buddha. Jakarta:

Dirjen Bimas Buddha.

Suranto, AW. (2011). Komunikasi Interpersonal. Yogyakarta: Graha Ilmu.

Sasa Djuarsa Sendjaja, Dkk. (2005). Pengantar Komunikasi. Jakarta: Universitas Terbuka.
Warsana. (2009). Petunjuk Pelaksanaan Penyuluh Agama Buddha. Jakarta: Direktorat Jendral Bimbingan Masyarakat Buddha Departemen Agama Republik Indonesia.

Walshe, Maurice. (2009). Khotbah-Khotbah Panjang sang Buddha. Digha Nikaya. Jakarta: Dhamma Citta press.

Wena Cintiawati, lanny anggawati. (2003). Sutta-Nipata. Klaten: Vihara Bodhivamsa.

Wursanto. (2005). Dasar-Dasar Ilmu Komunikasi. Yogyakarta : CV. Andi Offset. 